\title{
John W. Baldwin, Paris, 1200
}

\section{G. Matteo Roccati}

\section{(2) OpenEdition}

\section{Journals}

\section{Édition électronique}

URL : http://journals.openedition.org/studifrancesi/6547

DOI : 10.4000/studifrancesi.6547

ISSN : 2427-5856

\section{Éditeur}

Rosenberg \& Sellier

\section{Édition imprimée}

Date de publication : 1 septembre 2010

Pagination : 338

ISSN : 0039-2944

\section{Référence électronique}

G. Matteo Roccati, « John W. Baldwin, Paris, 1200 », Studi Francesi [En ligne], 161 (LIV | II) | 2010, mis en ligne le 30 novembre 2015, consulté le 09 janvier 2021. URL : http://journals.openedition.org/ studifrancesi/6547 ; DOI : https://doi.org/10.4000/studifrancesi.6547

Ce document a été généré automatiquement le 9 janvier 2021.

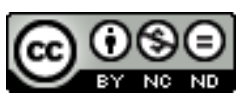

Studi Francesi è distribuita con Licenza Creative Commons Attribuzione - Non commerciale - Non opere derivate 4.0 Internazionale. 


\title{
John W. Baldwin, Paris, 1200
}

\author{
G. Matteo Roccati
}

\section{RÉFÉRENCE}

John W. BALDWIN, Paris, 1200, traduit de l'anglais (États-Unis) par Béatrice BONNE, Éditions Flammarion, département Aubier, 2006 («Collection historique»), pp. 472.

1 Bien que traduit, l'ouvrage a paru seulement en édition française. Il s'agit d'une monographie rédigée à partir de sources portant sur les années 1190-1210 faisant revivre la ville-dans ses différents aspects: économique, politique, religieux, intellectuel - au moment où l'on bâtit Notre-Dame et où Paris acquiert réellement l'importance d'une capitale. Dans le cadre de cette rassegna on retiendra surtout le portrait de Pierre le Chantre, le chapitre V sur Les écoles et le ch. VI, Plaisirs et peines, traitant notamment des festivités, des jongleurs, de la poésie lyrique profane et de la musique (où sont mis à profit les renseignements fournis par les textes littéraires, en particulier les romans de Jean Renart). 